\section{Peringkat Sukuk Berdasarkan Return on A sset dan Debt to Equity Ratio}

\section{A malia Cahyati, N urnasrina*}

Fakultas Ekonomi dan Bisnis Islam, UIN Sultan Syarif Kasim Riau, Indonesia

\begin{abstract}
A bstract
Purpose- This study is to examine the effect of return on assets (ROA) and debt to equity ratio (DER) on the rank of Sukuk listed on the Indonesia Stock Exchange (IDX). Methods- Data were collected by purposive sampling method with the number of companies sampled in the study were 7 companies with observations for 5 years. Findings- Results indicate that ROA and DER are proven to have a significant effect on Sukuk ratings. Implications- This study can be an evaluation for investors to determine investment decisions, especially Sukuk in Indonesia.
\end{abstract}

Keywords: Sukuk, ROA, DER

\begin{abstract}
A bstrak
Tujuan- Tujuan dari penelitian ini adalah untuk menguji pengaruh return on assets (ROA) dan debt to equity ratio (DER ) terhadap peringkat sukuk yang terdaftar di Bursa Efek Indonesia (BEI). Metode- Metode pengambilan sampel purposive sampling. Jumlah perusahaan yang dijadikan sampel dalam penelitian adalah 7 perusahaan dengan pengamatan selama 5 tahun. Hasil- penelitian ini menunjukkan ROA dan DER terbukti berpengaruh signifikan terhadap peringkat sukuk. Implikasi- temuan ini dapat menjadi bahan evaluasi bagi para investor untuk menentukan keputusan investasi, terutama sukuk di Indonesia.
\end{abstract}

Kata kunci: sukuk, ROA, DER

Pedoman Sitasi: Cahyati, A \& Nurnasrina, N. (2019). Peringkat Sukuk Berdasarkan Return on Asset dan Debt to Equity Ratio. SERAM BI: Jurnal Ekonomi M anajemen dan Bisnis Islam, 1(3), 101 - 110

D 0I: https:/ / doi.org/ 10.36407/ serambi.v1i3.132
SERAM BI

Received 12 Nov 2019

Revised 22 Dec 2019

Accepted 26 Dec 2019

Online first 30 Dec 2019

\section{Paper type}

Research paper

$\triangle$ Email korespondensi: nurnasrina@uinsuska.ac.id

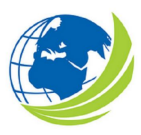

SERAMBI: Jurnal Ekonomi dan Bisnis Islam, Vol 1, No.3, 2019, pp. $101-110$ eISSN2685-9904 


\section{Pendahuluan}

Obligasi Syariah atau disebut sukuk merupakan suatu surat berharga jangka panjang berdasarkan prinsip syariah yang dikeluarkan emiten kepada pemegang obligasi syariah yang mewajibkan emiten untuk membayar pendapatan kepada pemegang obligasi syariah berupa bagi hasil/ margin/ fe, serta membayar kembali dana obligasi pada saat jatuh tempo (Fatwa DSN-MUI Nomor: 32/ DSN-MUI/ IX/ 2002).

Sukuk menggunakan beberapa fitur obligasi konvensional dan ekuitas yang secara ketat mengikuti praktik Islam. Sukuk tidak boleh terdiri dari biaya tambahan seperti bunga (Riba') dan semua perjanjian harus dirinci dan juga jelas untuk kedua belah pihak, misal nya ketidakpastian (Gharar) dan perjudian (Maysir). Sukuk merupakan bagian yang tidak terpisah dalam kepemilikan aset berwujud yang berkaitan dengan proyek tertentu atau aktivitas investasi khusus. Pemegang sukuk atau investor dapat memperoleh keuntungan karena didukung oleh aset dan memberikan tingkat perlindungan yang mungkin tidak tersedia dari obligasi konvensional. Sukuk sebagai obligasi konvensional lainnya perlu menjalani penilaian peringkat yang mencerminkan kelayakan kredit dari penerbit. Dalam hal ini, Sukuk dapat jatuh ke dalam risiko gagal bayar jika peringkat tersebut bermigrasi secara negatif sepanjang tahun penilaian yang jatuh tempo.

Peringkat sukuk merupakan hal yang penting, karena dapat membantu investor untuk membuat keputusan investasi yang benar dan terinformasi. Tujuan utama dari peringkat sukuk adalah untuk mengurangi asimetri informasi antara perusahaan dan investor (Hemraj, 2015). Semua sukuk harus dinilai dan peringkat harus diperbarui setiap tahun untuk mencerminkan kelayakan kredit yang sebenarnya dari penerbit. Investor yang kurang cermat dan tidak memiliki kapabilitas untuk memprediksi kinerja yang diharapkan dari Sukuk sangat bergantung kepada peringkat sukuk. Meskipun memiliki nilai straregis, faktor yang mempengaruhi peringkat sukuk menjadi perhatian bagi peneliti akhir-akhir ini. Berbagai studi mencoba untuk menjelaskan determinan peringkat sukuk, seperti dewan direksi (Elhaj, Muhamed, \& Ramli, 2018); faktor internal seperti profitabilitas, leverage, likuiditas, dan reputasi auditor (Melis, 2016; Pebruary, 2016; Al Haraqi \& Ningsih, 2017); faktor eksternal seperti makro ekonomi dan jenis industry (A rundina, Kartiwi, \& Omar, 2016); keandal an pengungkapan keuangan (Qizam \& Fong, 2019).

Hasil penelitian mengenai faktor yang dapat memprediksi peringkat sukuk memberikan bukti empiris yang beragam. Melis (2016) hanya berhasil membuktikan likuiditas sebagai determinan peringkat sukuk, sedangkan profitabilitas, current ratio, ROA, DER, reputasi auditor tidak terbukti signifikan secara statistik. Hasil berbeda ditemukan oleh Pebruary (2016) yang berhasil membuktikan leverage dan likuiditas sebagai penentu peringkat sukuk. ROA ditemukan signifikan mempengaruhi peringkat sukuk (AI Haraqi \& Ningsih, 2017) dan studi terbaru yang dilakukan Qizam dan Fong (2019) menemukan bahwa keandalan pengungkapan keuangan, leverage, rasio penjualan terhadap aset, pertumbuhan depresiasi, pertumbuhan pendapatan, ROI, pertumbuhan aset, dan pendapatan operasional merupakan faktor-faktor relevan untuk memprediksi peringkat sukuk, dengan leverage sebagai faktor yang paling dominan.

Penelitian lain mengenai pengaruh rasio keuangan dalam mempengaruhi peringkat sukuk atau peringkat obligasi dilakukan oleh Maliya (2015) yang menyebutkan bahwa rasio likuiditas dan rasio solvabilitas berpengaruh terhadap peringkat sukuk,sedangkan rasio produktivitas dan rasio profitabilitas tidak berpengaruh terhadap peringkat sukuk. Sedangkan menurut penelitian Fenny et al. (2017) menyatakan rasio likuiditas tidak berpengaruh terhadap peringkat obligasi, sedangkan rasio profabilitas dan rasio solvabilitas berpengaruh. Dalam penelitian Astuti (2017) disimpulkan bahwa rasio likuiditas, rasio produktivitas, dan rasio profitabilitas berpengaruh 
terhadap peringkat sukuk. Temuan berbeda Winanti et al. (2017) yang memberikan kesimpuln bahwa rasio likuiditas dan rasio profitabilitas tidak berpengaruh terhadap peringkat sukuk, sedangkan rasio poduktifitas dan rasio solvabilitas berpengaruh terhadap peringkat sukuk.

Selain belum adanya kesimpulan yang tidak konsisten mengenai faktor yang dapat memperdiksi peringkat sukuk. Situasi ini menuntut studi baru yang harus dilakukan, dan dengan demikian, kesenjangan yang coba tutupi adalah identifikasi faktor penentu peringkat sukuk dalam konteks perusahaan yang terdaftar di Bursa Efek Indonesia. Secara spesifik, penelitian ini menggunakan dua faktor yaitu return on assets (ROA) dan debt to equity ratio (DER) untuk memprediksi peringkat sukuk. Motivasi penelitian ini adalah untuk memberikan informasi yang bermanfaat tentang peringkat sukuk dan bukti konkret tentang penentunya sehingga dapat memberikan manfaat secara praktis kepada para investor sebagai acuan yang untuk mengambil keputusan investasi.

\section{Kajian Teori dan Pengembangan Hipotesis}

Teori Agensi memberikan dasar berpikir mengenai adanya kemungkinan konflik kepentingan antara pelaku dan agen. Konflik kepentingan ini dapat terjadi antara pemegang saham dan manajer perusahaan dan juga antara pemegang saham dan pemegang utang (Borhan dan Ahmad, 2018). Pemegang obligasi merupakan salah satu pemegang hutang perusahaan. Pemegang obligasi dapat memiliki perspektif yang berbeda mengenai cara pengelolaan perusahaan dibandingkan dengan para pemegang saham (Lustig, 2014). Pemegang obligasi lebih menyukai perusahaan dikelola dengan hati-hati sehingga dapat membayar utangnya tepat waktu. Sebaliknya, pemegang saham lebih suka perusahaan untuk melakukan investasi yang lebih berisiko untuk pertumbuhan dan ekspansi sehingga menghasilkan dividen yang lebih tinggi.

Teori dari peringkat sukuk juga dapat dijelaskan dari teori signaly. Teori ini secara ringkas menjelaskan bahwa manajemen perusahaan sebagai pihak pemberi sinyal, memberikan laporan keuangan perusahaan dan informasi non keuangan kepada lembaga pemeringkat yang dipilih. Lembaga pemeringkat sukuk kemudian melakukan proses pemeringkatan sesuai dengan prosedur sehingga dapat menerbitkan peringkat sukuk dan mempublikasikannya. Peringkat sukuk ini memberikan sinyal tentang kegagalan pembayaran utang sebuah perusahaan. Faktor fundamental seperti profitabilitas dan rasio hutang merupakan dua faktor yang paling sering menjadi acuan peneliti untuk memprediksi peringkat sukuk (Melis, 2016; Pebruary, 2016; Al Haraqi \& Ningsi h, 2017).

Profitabilitas mengacu pada kemampuan sebuah bisnis untuk menghasilkan keuntungan. Sebagian besar penelitian telah menemukan profitabilitas menjadi penentu signifikan positif peringkat. Tingkat pengembalian aset (ROA) biasanya digunakan sebagai proksi untuk profitabilitas dalam sebagian besar penelitian. Elhaj et al. (2015) menguji pengaruh profitabilitas pada 25 perusahaan publik yang terdaftar di Bursa Malaysia pada periode 2008 - 2012. Hasil penelitiannya berhasil membuktikan bahwa ROA memiliki dampak signifikan pada peringkat sukuk. Penelitian Iain oleh Souza Murciaet al. (2014) mengidentifikasi penentu rating kredit di Brazil telah juga ditemukan bahwa profitabilitas memiliki pengaruh signifikan positif terhadap peringkat kredit. ROA juga terbukti berpengaruh signifikan pada peringkat sukuk di Indonesia dan Malaysia (Setyani, 2013; Al Haraqi \& Ningsi h, 2017; Ab Hamid, Zakaria, \& Ab Aziz, 2014).

D ebt to Equity Ratio (DER) untuk mengukur proporsi penggunaan utang untuk membiayai investasi terhadap modal yang dimiliki. DER merupakan salah satu rasio leverage yang merupakan perbandingan hutang dengan ekuitas. Penelitian komprehensif dilakukan oleh 
Qizam dan Fong (2019) mengambil sampel tiga negara yaitu Indonesia, Malaysia dan Australia. Hasil penelitian mereka menemukan bahwa keandalan pengungkapan keuangan terbukti memiliki efek positif yang signifikan terhadap sukuk / peringkat obligasi untuk dua sampel, yaitu, Indonesia dan Malaysia, sedangkan untuk sampel Australia, tidak ada bukti signifikan yang ditemukan, baik dalam efek relevansi dan keandalan pada obligasi peringkat. Di Indonesia dan Malaysia (peringkat sukuk), keandalan pengungkapan keuangan lebih menonjol daripada relevansi, sedangkan di Australia (peringkat obligasi), relevansi dan keandalan bukan merupakan pertimbangan khusus dalam memasukkan pengungkapan keuangan pada kebijakan peringkat obligasi. Selanjutnya, leverage ditemukan menjadi yang paling berpengaruh dalam memiliki efek positif pada sukuk / peringkat obligasi (diikuti masing-masing dengan rasio penjualan terhadap aset, pertumbuhan depresiasi, pertumbuhan pendapatan, ROI, pertumbuhan aset, dan pendapatan operasional). Sejalan dengan penjelasan di atas maka hipotesis yang diajukan adalah:

$\mathrm{H}_{1}$ : ROA memiliki pengaruh signifikan terhadap peringkat sukuk

$\mathrm{H}_{2}$ : DER memiliki pengaruh signifikan terhadap peringkat sukuk

\section{M etode Penelitian \\ Prosedur sampel}

Populasi yang digunakan dalam penelitian ini adalah seluruh perusahaan yang menerbitkan obligasi syariah (sukuk). Teknik pengambilan sampel yang digunakan dalam penelitian ini adalah Purposive sampling yaitu teknik penentuan sampel dengan didasarkan pada kriteriakriteria tertentu (Hendryadi, Zannati, \& Tricahyadita, 2019). Total sampel yang memenuhi kriteria sebanyak 7 (tujuh) perusahaan dengan periode pengamatan selama lima tahun.

\section{Pengukuran V ariabel}

Peringkat Sukuk

Peringkat sukuk perusahaan berdasarkan peringkat yang dikeluarkan oleh PT. Pefindo secara umum terbagi menjadi dua yaitu investment grade (AAA, AA, BBB) dan non investment grade (BB, B, CCC, D). Menurut Wirawan (2010), perusahaan yang akan mengeluarkan obligasi harus memenuhi ketentuan dari pemerintah yaitu minimal hasil pemeringkatan dari lembaga pemeringkat obligasi yang terdaftar di Badan Pengawas Pasar Modal dan Lembaga Keuangan adalah sekurang-kurangnya BBB (investment grade). Skala yang digunakan adalah skala interval sesuai dengan peringkat yang di keluarkan oleh PT. Pefindo.

Return On A ssets (ROA)

Rasio ini menggambarkan kemampuan perusahaan untuk menghasilkan keuntungan dari setiap satu rupiah aset yang digunakan. Dengan mengetahui rasio ini, kita bisa menilai apakan perusahaan ini efisien dalam memanfaatkan aktivanya dalam kegiatan operasional perusahaan. Rasio ini juga memberikan ukuran yang lebih baik atas profitabilitas perusahaan karena menunjukkan efektivitas manajemen dalam menggunakan aktiva untuk memperoleh pendapatan. ROA diperoleh dengan cara:

$$
\mathrm{ROA}=\frac{\text { Net Income }}{\text { Total Assets }}
$$


D ebt To Equity Ratio (DER)

Rasio ini menunjukkan persentase penyediaan dana oleh pemegang saham terhadap pemberi pinjaman. Semakin tinggi rasio, semakin rendah pendanaan perusahaan yang disediakan oleh pemegang saham. Dari perspektif kemampuan membayar kewajiban jangka panjang, semakin rendah rasio akan semakin baik kemampuan perusahaan dalam membayar kewajiban jangka panjang.Rasio ini di cari dengan cara membandingkan antara seluruh utang, termasuk utang lancar dengan seluruh ekuitas. DER diperoleh dengan cara:

\section{DER $=\underline{\text { Total Debt }}$ Total Eauity}

Total hutang merupakan penjumlahan dari hutang lancar dengan hutang jangka panjang. Modal sendiri merupakan sumber dana yang berasal dari pemilik perusahaan.

\section{Teknik Analisis}

Teknik analisis yang digunakan adalah regresi linier berganda dengan bantuan program SPSS versi 20. Analisis regresi logistik adalah teknik statistik melalui koefisien parameter untuk mengetahui besarnya pengaruh variabel independen terhadap variabel dependen. Penelitian ini menggunakan analisis regresi logistik karena menggunakan 2 variabel bebas yaitu rasio(ROA) dan (DER) serta satu variabel terikat yaitu Peringkat Sukuk

, maka model persamaan regresi linier bergandanya adalah:

$Y=a+b 1 \times 1+b 2 \times 2$

Keterangan :

$\mathrm{Y}=$ Peringkat sukuk

$\mathrm{a}=$ Konstanta, yaitu nilai peringkat sukuk jika rasio ROA dan $\mathrm{DER}=0$

b1, b2, =Koefisien regresi yaitu nilai peningkatan atau penurunan peringkat sukuk yang

didasarkan pada ROA dan DER

$x 1=$ Return On Assets

x2 = Debt To Equity Ratio

\section{Hasil dan Diskusi}

\section{Analisis Deskriptif}

Hipotesis yang digunakan dalam penelitian ini diuji dengan model regresi linear berganda. Sebelum analisis regresi dilakukan, berikut ini ditampilkan hasil analisis deskriptif yang menjelaskan data penelitian secara umum.

Tabel 1. Rekapitulasi Data Analisis

\begin{tabular}{|c|c|c|c|}
\hline \multirow{2}{*}{ Emiten } & & \multicolumn{2}{|c|}{$\begin{array}{c}\text { Variabel } \\
\text { Independent }\end{array}$} \\
\cline { 3 - 4 } & \multirow{2}{*}{ Tahun } & \multicolumn{1}{|c|}{ ROA } & \multicolumn{1}{c|}{ DER } \\
\hline \multirow{3}{*}{ PT Indosat (ISAT) } & 2013 & 0.049 & 1.4 \\
\cline { 2 - 4 } & 2014 & 0.035 & 1.6 \\
\cline { 2 - 4 } & 2015 & 0.021 & 2.1 \\
\hline
\end{tabular}




\begin{tabular}{|c|c|c|c|}
\hline & 2016 & 0.022 & 1.7 \\
\hline & 2017 & 0.022 & 1.4 \\
\hline \multirow{5}{*}{$\begin{array}{c}\text { PT Summarecon Agung } \\
\text { (SMRA) }\end{array}$} & 2013 & 0.08 & 0.54 \\
\hline & 2014 & 0.09 & 0.73 \\
\hline & 2015 & 0.06 & 0.82 \\
\hline & 2016 & 0.03 & 0.91 \\
\hline & 2017 & 0.02 & 0.96 \\
\hline \multirow{5}{*}{ PT Timah (TINS) } & 2013 & 0.07 & 0 \\
\hline & 2014 & 0.07 & 0.01 \\
\hline & 2015 & 0.01 & 0 \\
\hline & 2016 & 0.03 & 0 \\
\hline & 2017 & 0.04 & 0.01 \\
\hline \multirow{5}{*}{ PT Angkasa Pura I (APAI) } & 2013 & 0.052 & 0.36 \\
\hline & 2014 & 0.063 & 0.51 \\
\hline & 2015 & 0.05 & 0.52 \\
\hline & 2016 & 0.049 & 0.97 \\
\hline & 2017 & 0.057 & 0.87 \\
\hline \multirow{5}{*}{ XL Axiata (EXCL) } & 2013 & 0.026 & 0.01 \\
\hline & 2014 & 0.007 & 0.02 \\
\hline & 2015 & 0.007 & 0.02 \\
\hline & 2016 & 0.007 & 0.01 \\
\hline & 2017 & 0.007 & 0.01 \\
\hline \multirow{5}{*}{$\begin{array}{l}\text { PT Sarana Multigriya } \\
\text { Finansial (SMFP) }\end{array}$} & 2013 & 0.019 & 2.32 \\
\hline & 2014 & 0.018 & 2.76 \\
\hline & 2015 & 0.025 & 1.59 \\
\hline & 2016 & 0.024 & 1.63 \\
\hline & 2017 & 0.025 & 1.44 \\
\hline \multirow{5}{*}{ Adira Finance (ADMF) } & 2013 & 0.06 & 4.2 \\
\hline & 2014 & 0.026 & 6.4 \\
\hline & 2015 & 0.023 & 5.4 \\
\hline & 2016 & 0.037 & 4.6 \\
\hline & 2017 & 0.05 & 4.1 \\
\hline
\end{tabular}

Sumber : D ata O Iahan, 2018

Tabel diatas menunjukkan pertumbuhan nilai ROA yang dihasilkan oleh PT Indosat, PT Summarecon Agung, PT Timah, PT Angkasa Pura I, XL Axiata, PT Sarana Multigriya Finansial, dan Adira Finance. ROA menunjukkan kemampuan manajemen dalam menghasilkan 
pendapatan dari pengelolaan asset yang dimilikinya. Berdasarkan tabel diatas dapat dilihat bahwa rata-rata nilai ROA paling tinggi diperoleh oleh PT Summarecon Agung dengan nilai rata-rata ROA 0.056\%. Hal iniberarti selamaperiodetahun 2013 sampai 2017, PT Summarecon Agung dapat dikatakan berada dalam kondisi keuangan yang baik. Hal berbeda dialami oleh PT Indosat, rata-rata nilai ROA adalah $-0.01366 \%$. Hal ini berarti pada periode tahun $2013-2017$ kinerja keuangan PT Indosat berada dalam posisi yang kurang baik.

DER menunjukkan perbandingan antara utang dan ekuitas perusahaan. Dari tabel diatas dapat dilihat bahwa rata-rata nilai DER paling tinggi diperoleh oleh Adira Finance 4.94\%. Hal ini berarti selama periode pengamatan, PT Adira Finance dapat dikatakan berada dalam kondisi keuangan yang cukup baik. Hal berbeda dialami oleh PT Timah, rata-rata nilai DER PT Timah adalah $0.00418 \%$. Hal ini berarti pada periode pengamatan, kinerja keuangan PT Timah memiliki DER terendah dibanding perusahaan yang dijadikan sampel dalam studi ini.

\section{A nalisis regresi}

Setelah asumsi normalitas dan asumsi klasik (heterokedastisitas, multikolinieritas dan autokorelasi) terpenuhi, maka selanjutnya melakukan interpretasi pada model regresi yang dihasilkan.

Evaluasi kecocokan model regresi

Evaluasi kecocokan model regresi dapat dilakukan dengan memperhatikan nilai koefisien determinasi dan uji F. Berdasarkan tabel 2 diketahui bahwa bahwa nilai adj. R Square sebesar 0,720. Artinya adalah bahwa kemampuan variabel independen (ROA dan DER) menjelaskan variasi peringkat sukuk adalah $72 \%$. Nilai $\mathrm{F}$ hitung sebesar 44,7 dengan menggunakan tingkat keyakinan 95\% dan tingkat signifikan 0,05. Berdasarkan hasil uji F diketahui bahwa nilai Fhitung sebesar 44,7 dengan tingkat signifikan sebesar 0,000 dan Ftabel sebesar 3,27, karena Fhitung $>$ Ftabel dengan tingkat signifikan $0<0,05$, yang berarti model regresi yang menempatkan Return On A sset (ROA) dan D ebt to Equity Ratio (DER) dapat digunakan.

Tabel 2. Hasil Regresi

\begin{tabular}{l|r|r|r|r|}
\hline Variabel & Koefisien & Std. error & t-value & Sig. \\
\hline (Constant) & 1.174 & .019 & 61.392 & .000 \\
ROA & -.057 & .013 & -4.526 & .000 \\
DER & .032 & .004 & 9.245 & .000 \\
Adjusted R Square & .720 & & & \\
F-Statistics & 44.7 & & & \\
\hline
\end{tabular}

Sumber: diolah (2018)

Pembahasan

Berdasarkan tabel diatas, maka diperoleh persamaan regresi yang dihasilkan adalah:

$Y=1,174+(-0,057) \times 1+0,032 \times 2$

Dari persamaan regresi diatas dapat dijelaskan sebagai berikut:

Koefisien regresi variabel ROA (X1) sebesar -0,057, artinya jika variabel independen lain nilainya tetap dan ROA mengalami kenaikan $1 \%$ maka peringkat sukuk (Y) akan mengalami penurunan sebesar 0,057 . Koefisien bernilai negatif artinya terjadi hubungan negatif antara ROA dengan peringkat sukuk, semakin naik ROA maka semakin turun peringkat sukuk. Nilai 
signifikansi untuk pengaruh ROA terhadap Peringkat Sukuk sebesar $0<0,05$ dan nilai t hitung 4,526 < t tabel 2,035, sehingga dapat disimpulkan bahwa $\mathrm{H} 0$ ditolak yang berarti tidak terdapat pengaruh ROA terhadap Peringkat Sukuk.

Hasil studi ini mengindikasikan bahwa semakin tinggi profitabilitas, maka akan menurunkan peringkat sukuk (negatif). Dari sisi signifikansi, studi ini mendukung temuan penelitian sebelumnya (Pebruari, 2016; Setyani, 2013; Al Haraqi \& Ningsih, 2017; Ab Hamid, Zakaria, \& Ab Aziz, 2014). Namun dari sisi arah, studi ini berbeda dengan temuan sebelumnya yang menyimpulkan ROA berpengaruh signifikan terhadap rating sukuk dengan arah pengaruh yang positif.

Koefisien regresi variabel DER (X2) sebesar 0,032, artinya jika variabel independen lainnya tetap dan DER mengalami kenaikan $1 \%$ maka peringkat sukuk akan mengalami kenaikan sebesar 0,032. Koefisien bernilai positif artinya terjadi hubungan positif antara DER dengan peringkat sukuk, semakin naik DER maka semakin naik peringkat sukuk. Nilai signifikansi untuk pengaruh DER terhadap Peringkat Sukuk sebesar $0<0,05$ dan nilai thitung 9,245 $>$ t tabel 2,035, sehingga dapat disimpulkan bahwa $\mathrm{H}_{1}$ diterima yang berarti terdapat pengaruh $\mathrm{DER}$ terhadap Peringkat Sukuk.

Pengembangan pasar Sukuk sebagai alternatif dari pasar obligasi konvensional yang ada telah memunculkan masalah ketersediaan dan keakuratan beberapa peringkat penerbitan Sukuk. Hasil penelitian ini membuktikan bahwa perusahaan yang memiliki profitabilitas tinggi memiliki kecenderungan peringkat sukuk yang rendah sehingga berbeda dengan asumsi awal yang digunakan. Hal ini juga di dukung oleh fakta dan penjelasan dari Otoritas Jasa Keuangan (2018) pada akhir tahun 2018 yang akan mengevaluasi proses pemeringkatan obligasi, karena ditemukan beberapa perusahaan mengalami gagal bayar. Kondisi ini memperlihatkan bahwa peringkat obligasi (termasuk sukuk) belum akurat sepenuhnya sehingga merugikan investornya.

\section{Kesimpulan}

Penelitian ini memiliki tujuan untuk menjelaskan peringkat sukuk dari sisi profitabilitas dan leverage. Hasil penelitian menemukan bahwa, baik profitabilitas (ROA) maupun leverage (DER), keduanya memiliki efek signifikan terhadap peringkat sukuk. Meskipun demikian, arah hubungan ROA (negative) dan DER (positif) ini berbeda dengan bukti empiris sebel umnya perlu mendapatkan perhatian, terutama dari sisi keakuratan peringkat sukuk. Oleh karenanya, kesimpulan penelitian ini belum bersifat final sehingga dibutuhkan penelitian lanjutan yang lebih luas untuk menguji ulang hubungan kedua variabel tersebut.

\section{Implikasi}

Beberapa implikasi berasal dari hasil penelitian antara lain: pertama, perusahaan yang akan menerbitkan Sukuk harus secara konsisten mempertahankan tingkat keuntungan yang tinggi dan mempertimbangkan level leverage yang memadai untuk memastikan bahwa Sukuk yang diterbitkan memiliki peringkat yang lebih tinggi. Kedua, pihak Otoritas Jasa Keuangan (OJK) perlu mengevaluasi pemeringkatan obligasi yang terbukti mengalami masalah gagal bayar (data OJK tahun 2018 menunjukkan beberapa perusahaan mengalami gagal bayar).

\section{Keterbatasan}

Penelitian ini hanya berfokus pada dua rasio keuangan yaitu ROA dan DER sehingga faktor lainnya dapat menjadi pertimbangan untuk penelitian di masa depan. Merujuk studi Qizam dan Fong (2019), penelitian berikutnya dapat mengambil sampel yang lebih besar dan periode 
pengamatan yang lebih lama (misalnya 10 tahun). Selain itu, selain profitabilitas dan leverage, rasio penjualan terhadap aset, pertumbuhan depresiasi, pertumbuhan pendapatan, ROI, pertumbuhan aset, dan pendapatan operasional dapat digunakan sebagai variabel tambahan.

\section{D aftar Pustaka}

Ab Hamid, N. H., Zakaria, N. B., \& Ab Aziz, N. H. (2014). Firms' performance and risk with the presence of Sukuk rating as default risk. Procedia-Social and Behavioral Sciences, 145, 181-188.

Afiani, D. (2013). Pengaruh Likuiditas, Produktifitas, Profitabilitas, dan Leverage Terhadap Peringkat Sukuk (Studi Empiris pada Bank Umum Syariah dan Unit Usaha Syariah Periode 2008-2010). Accounting A nalysis Journal 2(1).

Al Haraqi, M. S., \& Ningsih, E. S. (2017). Pengaruh Return on Asset, Secure dan Maturity Terhadap Rating Sukuk. Jurnal IImiah M ahasiswa Ekonomi A kuntansi, 2(4), 116-124.

Arundina, T., Kartiwi, M., \& Omar, M. A. (2016). Artificial Intelligence for Islamic Sukuk Rating Predictions. In Artificial Intelligence in Financial M arkets (pp. 211-241). Palgrave Macmillan, London.

Astuti, R. P. (2017). Pengaruh likuiditas, produktivitas, profitabilitas, terhadap peringkat sukuk. Jurnal IImu M anajemen dan A kuntansi Terapan (JIM A T), 8(1), 80-94.

Borhan, N. A., \& A hmad, N. (2018). Identifying the determinants of Malaysian corporate Sukuk rating. International Journal of Islamic and $\mathrm{M}$ iddle Eastern Finance and $\mathrm{M}$ anagement, 11(3), 432448.

Elhaj, M. A. A., Muhamed, N. A., \& Ramli, N. M. (2015). The influence of corporate governance, financial ratios, and Sukuk structure on Sukuk rating. Procedia E conomics and Finance, 31, 6274.

Elhaj, M. A., Muhamed, N. A., \& Ramli, N. M. (2018). The effects of board attributes on Sukuk rating. International Journal of Islamic and $M$ iddle Eastern Finance and $M$ anagement, 11(2), 312330.

Fenny, F., Effendi, R., \& Artina, N. (2016). Analisis Pengaruh Likuiditas, Profitabilitas, Dan Solvabilitas Terhadap Peringkatan Obligasi Syariah Pada Perusahaan Yang Menerbitkan Obligasi Syariah Di Bursa Efek Indonesia Periode 2014-2016.

Gujarati, D.N. and Porter, D.C. (2010),Basic Econometrics, 5th ed., McGraw Hill, N ew York, NY

Hendryadi., Tricahyadinata, I., \& Zannati, R. (2019). Metode Penelitian: Pedoman Penelitian Bisnis dan Akademik. Jakarta: Lembaga Pengembangan Manajemen dan Publikasi Imperium

https:/ / www.cnbcindonesia.com/ market/ 20181211113843-17-45825/ banyak-gagal-bayar-ojkreview-proses-pemeringkatan-obligasi

Lustig, Y. (2014),The Investment Assets Handbook: A Definitive Practical Guide to Asset Classes, Harriman House Limited, Hampshire

Malia, L. (2015). Pengaruh Rasio Keuangan Terhadap Peringkat Sukuk. Jurnal IImu \& Riset A kuntansi Sekolah Tinggi IImu Ekonomi Indonesia (STIESIA) Surabaya, 4(11).

Melis, K. (2016). Analisis Faktor-Faktor Yang Mempengaruhi Rating Sukuk. Jurnal IImiah $M$ ahasiswa FEB, 3(2).

Pebruary, S. (2016). Pengaruh Rasio Profitabilitas, Rasio Likuiditas, Rasio Leverage dan Pendapatan Bunga Terhadap Rating Sukuk Korporasi Periode 2010-2013. Jurnal Dinamika Ekonomi \& Bisnis, 13(1).

Qizam, I., \& Fong, M. (2019). Developing financial disclosure quality in sukuk and bond market: Evidence from Indonesia, Malaysia, and Australia. Borsa Istanbul Review, 19(3), 228-248.

Winanti, E., Nurlaela, S., \& Titisari, K. H. (2017). Pengaruh Rasiolikuiditas, Rasio Produktivitas, Rasio Profitabilitas, Dan Rasio Solvabilitas Terhadap Peringkat Sukuk. Jurnal Akuntansi dan Pajak, 18(01). 
Wirawan, Y.G. (2010). Pemeringkatan Obligasi Perdana Sebagai Pemicu Manajemen Laba: Bukti Empiris Dari Pasar Modal Indonesia, Purwokerto: Si mposium Nasional A kuntansi XIII. 1315 Oktober, 2010

\begin{abstract}
A bout Authors
Amalia Cahyati dan Nurnasrina adalah mahasiswa dan dosen di Fakultas Ekonomi dan Bisnis Islam, UIN Sultan Syarif Kasim Riau, Indonesia. Korespondensi penulis dapat diarahkan ke email: nurnasrina@uin-suska.ac.id
\end{abstract}

Accepted author version posted online: 30 Dec 2019

$$
\text { (c) (1) }
$$

(C) 2019The Author(s). This open access article is distributed under a Creative Commons Attribution (CC-BY) 4.0 license 